\title{
The metabolism of nitrogen, calcium and phosphorus in undernourished children
}

\section{6*. The effect of partial or complete replacement of rice in poor vegetarian diets by kaffir corn (Sorghum vulgare)}

\author{
By P. P. KURIEN, M. NARAYANARAO, M. SWAMINATHAN AND \\ V. SUBRAHMANYAN
}

Central Food Technological Research Institute, Mysore, India

(Received I7 November I959-Revised 25 Fanuary 1960)

Kaffir corn (Sorghum vulgare) is one of the important food crops widely cultivated in different parts of India. Over considerable parts of the Deccan plateau and Cental India it is eaten as a staple food by millions of people. It is also grown to a considerable extent in other countries, especially in Africa, China, the U.S.A. and Latin America. The grain is usually ground to flour and cooked and eaten as dumplings or unleavened bread. The poorer classes generally prefer kaffir corn to softer grains like rice because of its cheapness and sustaining qualities. Diets containing kaffir corn and other cereals have been compared in growth experiments on albino rats (Sur, Swaminathan \& Subrahmanyan, I955; Subrahmanyan, Kuppuswamy, Ramarao, Swaminathan \& Bhatia, 1954). These studies have shown that the general nutritive value of a poor vegetarian diet containing kaffir corn is higher than that of rice, but slightly less than that of similar diets containing ragi (Eleusine coracana) or wheat. Our metabolic studies carried out on children in India have so far been confined to diets containing rice and ragi (Murthy, Reddy, Swaminathan \& Subrahmanyan, 1955; Joseph, Narayanarao, Ganapathy, Swaminathan \& Subrahmanyan, I958; Joseph, Kurien, Swaminathan \& Subrahmanyan, I959). We have not previously reported any metabolic studies in children on kaffir-corn diets. Because of the acute shortage of rice in the country, the use of kaffir corn and other millets as partial substitutes for rice needs to be studied. The present paper describes the results of investigations on the effects of partial or complete replacement of rice in a poor Indian diet by kaffir corn on the metabolism of nitrogen, calcium and phosphorus in children.

\section{EXPERIMENTAL}

Subjects. Seven boys aged IO-I I years who were residents of a boarding home in Mysore City were selected as experimental subjects. All of them belonged to the poorer classes and were accustomed to eating millets such as kaffir corn or ragi. They were clinically examined and found to be free from any disease likely to interfere with the metabolic experiment. They had been dewormed by santonin given orally 
about a month before the experiment. Information about their ages, heights and weights is given in Table $\mathbf{r}$.

Plan of experiment. The experiment consisted of four periods. The proportions of rice to kaffir corn in the diet given during different periods were: period $\mathrm{I}$, rice only (rice diet); period 2, rice 3 parts and kaffir corn I part ( $25 \%$ kaffir-corn diet); period 3 , rice I part and kaffir corn I part (50\% kaffir-corn diet); and period 4 , kaffir corn only (kaffir-corn diet). The other ingredients in the diets were the same throughout. The subjects were fed on each diet for a period of 15 days, the first 10 days being treated as a preliminary period of adjustment. Urine and faeces were collected for analysis during the last 5 days of each period.

Table I. Ages, heights and weights of the children at the beginning of the test

Child no
I
2
3
4
5
6
7

Age (years)
II
IO
I I
II
10
10
II

Height (cm)
137
135
140
135
131
130
135

Weight $(\mathrm{kg})$
$28 \cdot 6$
23.6
24.6
24.6
25.5
23.6
24.6

Table 2. Percentage composition of the raw milled rice and kaffir corn used

\begin{tabular}{|c|c|c|}
\hline & Raw milled rice & Kaffir corn \\
\hline Moisture & $9^{\circ} 9$ & $12 \cdot 2$ \\
\hline Protein $(\mathrm{N} \times 6.25)$ & 6.7 & $7 \cdot 7$ \\
\hline Fat (ether extractives) & 0.5 & $2 \cdot 2$ \\
\hline Ash & 0.5 & $I \cdot 7$ \\
\hline Starch & $8 I \cdot 4$ & $66 \cdot 5$ \\
\hline Total sugars & $0 \cdot 3$ & $I \cdot 3$ \\
\hline Crude fibre & 0.2 & $2 \cdot 8$ \\
\hline $\begin{array}{l}\text { Pentosans and other hemi- } \\
\text { celluloses (by difference) }\end{array}$ & 0.5 & $5 \cdot 6$ \\
\hline Calcium & 0.01 & 0.037 \\
\hline Phosphorus (total) & 0.139 & 0.245 \\
\hline Phytate phosphorus & 0.087 & 0.194 \\
\hline Calories (kcal/100 g) & 357 & 322 \\
\hline
\end{tabular}

Chemical composition of kaffir corn and rice. The chemical composition of the samples of rice and kaffir corn used was determined by the methods of the Association of Official Agricultural Chemists (1955). The phytate P was estimated by the method of McCance \& Widdowson (1935). The results are presented in Table 2.

Experimental diets and the feeding of the subjects. The mean composition of the diets eaten daily by the subjects is shown in Table 3. The diet consisted mainly of cereals and contained small amounts of pulses, vegetables, meat and milk: it was similar to that eaten in normal times by most children of the classes to which the experimental subjects belonged. They were fed three times a day. Breakfast consisted of a pancake made of rice flour or of kaffir-corn flour or of both, chutney made from red gram dhal and a cup of tea. Lunch and dinner consisted of cooked rice or unleavened bread (rotti) made from kaffir-corn flour or of both, vegetable soup (a 
preparation containing pulses, tamarind, chillies, spices, salt and vegetables and dilute 'buttermilk'. The 'buttermilk' was prepared by reconstituting with water a part of the milk powder included in the diet and then converting it into sour curd by seeding with a small quantity ( $\mathrm{\%} \%$ by volume) of sour curd and incubating at $30^{\circ}$ for $16 \mathrm{~h}$. The sour curd thus obtained was diluted with four times its volume of water and

\section{Table 3. Mean daily intake of foodstuffs and nutrients by the children} on the different diets

Foodstuff or nutrient

Rice, raw milled
Kaffir corn (Sorghum vulgare)
Red gram dhal (Cajanus indicus)
Groundnut oil
Potato
Brinjal (Solanum melongena)
Amaranth leaves (Amaranthus gangeticus)
Radish
Onions
Tamarind fruit pulp (Tamarindus indicus)
Coconut kernel
Meat
Skim-milk powder
Common salt
Cane sugar
Condiments (garlic, coriander seeds, mustard, red chillies, and
turmeric)
Tea leaves

Rice, raw milled

Groundnut oil

Potato

Brinjal (Solamum melongena)

Radish

Onions

Tamarind fruit pulp (Tamarindus indicus)

Coconut kernel

Common salt

Condiments (garlic, coriander seeds, mustard, red chillies, and

Tea leaves

Calories (kcal)

Protein $(\mathrm{N} \times 6.25)(\mathrm{g})$

Fat $(g)$

Carbohydrate (g)

Calcium (mg)

Phosphorus (total) (mg)

Phytate phosphorus (mg)

Thiamine (mg)

Nicotinic acid (mg)

Vitamin A activity (mainly as carotene) (i.u.)

\begin{tabular}{|c|c|c|c|}
\hline \multicolumn{3}{|c|}{ Diet } & \\
\hline Rice & $\begin{array}{c}25 \% \\
\text { kaffir } \\
\text { corn }\end{array}$ & $\begin{array}{l}50 \% \\
\text { kaffir } \\
\text { corn }\end{array}$ & $\begin{array}{l}\text { Kaffir } \\
\text { corn }\end{array}$ \\
\hline
\end{tabular}

Nutrients*

\begin{tabular}{rrrr}
360 & 270 & \multicolumn{1}{c}{180} & \multicolumn{1}{c}{-} \\
- & \multicolumn{1}{c}{90} & \multicolumn{1}{c}{180} & \multicolumn{1}{c}{360} \\
$25 \cdot 6$ & $25 \cdot 6$ & $25 \cdot 6$ & $25 \cdot 6$ \\
$25 \cdot 6$ & $25 \cdot 6$ & $25 \cdot 6$ & $25 \cdot 6$ \\
$25 \cdot 6$ & $25 \cdot 6$ & $25 \cdot 6$ & $25 \cdot 6$ \\
$13 \cdot 0$ & $13 \cdot 0$ & $13 \cdot 0$ & $13 \cdot 0$ \\
$13 \cdot 0$ & $13 \cdot 0$ & $13 \cdot 0$ & $13 \cdot 0$ \\
$13 \cdot 0$ & $13 \cdot 0$ & $13 \cdot 0$ & $13 \cdot 0$ \\
$12 \cdot 3$ & $12 \cdot 3$ & $12 \cdot 3$ & $12 \cdot 3$ \\
$11 \cdot 3$ & $11 \cdot 3$ & $11 \cdot 3$ & $11 \cdot 3$ \\
$8 \cdot 3$ & $8 \cdot 3$ & $8 \cdot 3$ & $8 \cdot 3$ \\
$28 \cdot 0$ & $28 \cdot 0$ & $28 \cdot 0$ & $28 \cdot 0$ \\
$6 \cdot 4$ & $6 \cdot 4$ & $6 \cdot 4$ & $6 \cdot 4$ \\
$14 \cdot 4$ & $14 \cdot 4$ & $14 \cdot 4$ & $14 \cdot 4$ \\
$11 \cdot 0$ & $11 \cdot 0$ & $11 \cdot 0$ & $11 \cdot 0$ \\
$9 \cdot 6$ & $9 \cdot 6$ & $9 \cdot 6$ & $9 \cdot 6$ \\
$2 \cdot 0$ & $2 \cdot 0$ & $2 \cdot 0$ & $2 \cdot 0$
\end{tabular}

$\begin{array}{rrrr}1849 & 1819 & 1787 & 1725 \\ 40 & 40 & 41 & 43 \\ 36 & 37 & 39 & 42 \\ 344 & 331 & 319 & 294 \\ 355 & 381 & 410 & 441 \\ 744 & 835 & 928 & 1091 \\ 364 & 461 & 557 & 750 \\ 0.59 & 0.81 & 1 \cdot 03 & 1 \cdot 47 \\ 7.67 & 8 \cdot 21 & 8 \cdot 75 & 9 \cdot 83 \\ 776 & 898 & 1020 & 1265\end{array}$

* All the values (except for protein, calcium and phosphorus which were determined according to the methods referred to in the text) were calculated from figures given by Aykroyd, Patwardhan \& Ranganathan (1956).

agitated with a stirrer for 5 min to yield 'buttermilk'. Records of the food eaten daily by the subjects were kept throughout the experiment. Complete duplicates of all dishes eaten by each subject were collected daily, dried in an air oven at $95^{-100^{\circ}}$ and weighed. They were powdered and analysed for $\mathrm{N}, \mathrm{Ca}$ and $\mathrm{P}$.

Collection and preservation of urine and faeces. The procedure for the collection and preservation of urine and faeces was that of Murthy, Swaminathan \& Subrahmanyan (1954). Carmine was used as a marker for the collection of faeces. A check 
on the proper collection of urine was maintained by determining the daily excretion of creatinine.

Analytical methods. N, Ca and $\mathrm{P}$ in food, urine and faeces were determined by the method of Murthy et al. (1954). All the analyses were carried out in duplicate.

\section{RESULTS}

Nitrogen. The results for $\mathrm{N}$ metabolism are given in Table 4 . The mean daily intake of $\mathrm{N}$ from the different diets increased slightly with the increase in the amount of kaffir corn in the diet and ranged from 6.34 to $6.91 \mathrm{~g}$ (equivalent to about $40-43 \mathrm{~g}$ protein). The mean daily excretion of $\mathrm{N}$ in the faeces increased as the level of kaffir corn in the diet was raised and was highest $(3.08 \mathrm{~g})$ on the diet containing the whole of the cereal as kaffir corn. The apparent digestibility coefficients

$$
\frac{\mathrm{N} \text { intake - faecal } \mathrm{N}}{\mathrm{N} \text { intake }} \times 100
$$

of the proteins in the different diets were: rice diet $747 \%, 25 \%$ kaffir-corn diet $69.3 \%, 50 \%$ kaffir-corn diet $63.7 \%$, and kaffir-corn diet $55.4 \%$. The mean daily $\mathrm{N}$ retention on the different diets was $\mathrm{I} \cdot 80, \mathrm{I} \cdot 55, \mathrm{I} \cdot 28$ and $0 \cdot 88 \mathrm{~g}$, respectively. All the subjects were in positive $\mathrm{N}$ balance.

Table 4. Mean daily intake, excretion and balance of nitrogen of boys on the different diets

$\begin{array}{lcc}\text { Diet } & \begin{array}{c}\text { Calorie } \\ \text { value } \\ \text { (kcal/day) }\end{array} & \begin{array}{c}\text { Intake } \\ (\mathrm{g})\end{array} \\ \text { Rescription } & \mathbf{1 8 4 9} & 6.34 \\ \text { Rice } & 1819 & 6.42 \\ \mathbf{2 5} \% \text { kaffir corn } & \mathbf{1 7 8 7} & 6.50 \\ 50 \% \text { kaffir corn } & \mathbf{1 7 2 5} & 6.91 \\ \text { Kaffir corn } & \\ \text { Standard error of } \\ \text { the mean (18 d.f.) }\end{array}$

\begin{tabular}{ccc}
\multicolumn{3}{c}{ Excretion (g) } \\
$\overbrace{\text { Urinary }}$ & Faecal & Total \\
2.93 & 1.60 & 4.53 \\
2.90 & 1.97 & 4.87 \\
2.86 & 2.36 & 5.22 \\
2.95 & 3.08 & 6.03
\end{tabular}

$\begin{array}{cc}\begin{array}{c}\text { Apparent } \\ \text { digesti- } \\ \text { bility } \\ \text { coefficient } \\ (\%)\end{array} & \begin{array}{c}\text { Balance } \\ (\mathrm{g})\end{array} \\ 74.7 & +\mathrm{I} .80 \\ 69.3 & +\mathrm{I} .55 \\ 63.7 & +\mathrm{I} .28 \\ 55.4 & +0.88 \\ \pm \mathrm{I} .42 & \pm 0.085\end{array}$

Calcium. The results of the metabolic study are given in Table 5. All the subjects were in positive balance on the different diets. The $\mathrm{Ca}$ intake increased slightly as the level of kaffir corn in the diet was raised. The mean daily retention of $\mathrm{Ca}$ on the different diets was: rice diet $123 \mathrm{mg}, 25 \%$ kaffir-corn diet $109 \mathrm{mg}, 50 \%$ kaffir-corn diet $97 \mathrm{mg}$ and kaffir corn diet $74 \mathrm{mg}$. The Ca retention on the different diets decreased with the increase in the level of kaffir corn in the diet.

Phosphorus. The results of the metabolic study are given in Table 5. All the subjects were in positive $P$ balance on the different diets. The intake of $P$ was lowest on the rice diet and increased as the level of kaffir corn in the diet was raised. The mean daily retention of $\mathrm{P}$ on the different diets was: rice diet $169 \mathrm{mg}, 25 \%$ kaffir-corn diet $204 \mathrm{mg}, 50 \%$ kaffir-corn diet $233 \mathrm{mg}$ and kaffir-corn diet $309 \mathrm{mg}$.

Faeces. The dry weights of the faeces on the different diets were: rice diet 23.9 , $25 \%$ kaffir-corn diet $30 \cdot 8,50 \%$ kaffir-corn diet 38.8 and kaffir-corn diet $53.0 \mathrm{~g} /$ day. 
Table 5. Mean daily intake, excretion and balance of calcium and phosphorus of boys on the different diets

\begin{tabular}{|c|c|c|c|c|c|c|}
\hline \multicolumn{7}{|l|}{ Diet } \\
\hline \multirow[b]{2}{*}{ Description } & \multirow{2}{*}{$\begin{array}{c}\text { Calorie } \\
\text { value } \\
\text { (kcal/day) }\end{array}$} & \multirow[b]{2}{*}{$\begin{array}{c}\text { Intake } \\
\text { (mg) }\end{array}$} & \multicolumn{3}{|c|}{ Excretion (mg) } & \multirow[b]{2}{*}{$\begin{array}{c}\text { Balance } \\
\text { (mg) }\end{array}$} \\
\hline & & & Urinary & Faecal & Total & \\
\hline \multicolumn{7}{|c|}{ Calcium } \\
\hline Rice & I849 & 355 & 57 & 175 & 232 & +123 \\
\hline $25 \%$ kaffir corn & 1819 & $38 r$ & 49 & 223 & 272 & +109 \\
\hline $50 \%$ kaffir corn & 1787 & 410 & 55 & $25^{8}$ & 313 & $\begin{array}{r}+97 \\
\end{array}$ \\
\hline Kaffir corn & 1725 & $44 I$ & 50 & 317 & 367 & +74 \\
\hline $\begin{array}{l}\text { Standard error of the } \\
\text { mean ( } 8 \text { d.f.) }\end{array}$ & & & & & & $\pm 5^{\circ} 4$ \\
\hline \multicolumn{7}{|c|}{ Phosphorus } \\
\hline Rice & I 849 & 744 & 296 & 279 & 575 & + \pm 69 \\
\hline $25 \%$ kaffir corn & 1819 & 835 & 254 & 377 & 631 & +204 \\
\hline $50 \%$ kaffir corn & 1787 & 928 & 292 & 403 & 695 & +233 \\
\hline Kaffir corn & 1725 & $\operatorname{rog} 1$ & 232 & 550 & 782 & +309 \\
\hline $\begin{array}{l}\text { Standard error of the } \\
\text { mean (1 } 8 \text { d.f.) }\end{array}$ & & & & & & $\pm 17 \cdot 9$ \\
\hline
\end{tabular}

\section{DISCUSSION}

Kaffir corn and other millets, in view of their high roughage content, are generally considered coarse foods as compared to raw milled rice. A sudden change from a rice diet to a kaffir-corn diet generally causes digestive upsets in habitual rice eaters. The subjects of the present study were accustomed to a mixed diet containing rice, kaffir corn and other millets. All of them readily ate the diets containing kaffir corn and none experienced digestive disorders. The sample of kaffir corn used contained $8.4 \%$ roughage, i.e. cellulose and hemicelluloses. The mean daily faecal bulk increased directly with the level of kaffir corn in the diet. Other workers have made similar observations with diets based on wholemeal bread (McCance \& Walsham, 1948-9; Widdowson \& McCance, I954), unpolished rice (Cullumbine, I950; Joseph et al. I958) and ragi (Joseph et al. 1959).

Nitrogen. The mean daily protein intake $(40-43 \mathrm{~g})$ was lower than the recommended allowances of $57 \mathrm{~g}$ for children of this age (Indian Council of Medical Research: Nutrition Advisory Committee, r944). Nevertheless, all the children were in positive $\mathrm{N}$ balance. The mean apparent digestibility of the proteins in the diet and the mean retention of $\mathrm{N}$ progressively decreased as the level of kaffir corn in the diet was increased. The results are similar to those reported earlier by Joseph et al. (1959) in experiments with diets containing ragi.

Calcium. The mean daily $\mathrm{Ca}$ intake on the different diets ranged from 0.35 to $0.44 \mathrm{~g}$ and was very much lower than the recommended daily allowance of $\mathrm{I} g$ for children of this age group (Indian Council of Medical Research: Nutrition Advisory Committee, 1944). Nevertheless, all the children were in slight positive balance. The mean daily retention of $\mathrm{Ca}$ decreased as the level of kaffir corn in the diet was raised, which may have been due to the high phytate $\mathbf{P}$ content of kaffir corn as compared 
with raw milled rice (Table I). Widdowson \& Thrussell (I95I) observed that the intake and retention of $\mathrm{Ca}$ in German boys on a diet based on wholemeal bread were 0.75 and $0.085 \mathrm{~g}$, respectively. According to Widdowson \& McCance (1954) a daily retention of $0.18 \mathrm{~g}$ Ca may be essential for optimum growth and bone development in children. Judged on this basis, none of the diets used in the present study promoted adequate $\mathrm{Ca}$ retention. In this connexion it may be of interest to mention that Nicholls \& Nimalasuriya (1939) presented evidence indicating that Sinhalese children in the poorer classes frequently received not more than $0.2-0.4 \mathrm{~g}$ of $\mathrm{Ca}$ daily from their diet and yet their bones were normal in structure and composition. The children, however, were small in stature. These authors suggested that a process of adaptation to low levels of $\mathrm{Ca}$ intake had taken place.

Phosphorus. The mean $\mathrm{P}$ intake on the different diets ranged from 0.74 to $\mathrm{r} \cdot 09 \mathrm{~g}$. A large part $(48-70 \%)$ of $P$ in the diet was in the form of phytate $P$ (Table 3 ). Nevertheless, the mean daily retention of $P$ on the different diets ranged from 0.17 to $0.3 \mathrm{I} g$. These findings are similar to those of Widdowson $\&$ Thrussell (I95I) who observed that the intake and retention of $\mathrm{P}$ in German children on a diet based on wholemeal bread were $2.5 \mathrm{I}$ and $0.23 \mathrm{~g}$, respectively.

\section{SUMMARY}

r. The effect on the metabolism of nitrogen, calcium and phosphorus of replacing $25 \%, 50 \%$ or all of the rice in a poor Indian diet by kaffir corn was studied in seven boys aged IO-I I years.

2. The daily intake of $\mathrm{N}$ was nearly the same (equivalent to about $40-43 \mathrm{~g}$ protein) with all the diets.

3. The apparent digestibility coefficients of the protein and the mean daily $\mathrm{N}$ retentions diminished as the proportion of kaffir corn in the diet was increased. All the subjects were in positive $\mathrm{N}$ balance.

4. Although the addition of kaffir corn led to a higher $\mathrm{Ca}$ intake, the amount of $\mathrm{Ca}$ retained decreased as the proportion of kaffir corn in the diet was increased.

5. Kaffir corn also provided a higher $P$ intake, which resulted in a higher $P$ retention.

We are grateful to Mr A. N. Sankaran and Miss K. Indiramma for the statistical analysis of the results and to Mr V. A. Daniel for technical assistance.

\section{REFERENCES}

Association of Official Agricultural Chemists (1955). Official Methods of Analysis, 8th ed. Washington: Association of Official Agricultural Chemists.

Aykroyd, W. R., Patwardhan, V. N. \& Ranganathan, S. (1956). The Nutritive Value of Indian Foods and the Planning of Satisfactory Diets, 5 th ed. New Delhi: Manager of Publications.

Cullumbine, H. (1950). Brit. F. Nutr. 4, I29.

Indian Council of Medical Research: Nutrition Advisory Committee (1944). Report of the Scientific Advisory Board for the Year 1944. New Delhi: Indian Council of Medical Research.

Joseph, K., Kurien, P. P., Swaminathan, M. \& Subrahmanyan, V. (1959). Brit. F. Nutr. 13, 213.

Joseph, K., Narayanarao, M., Ganapathy, S., Swaminathan, M. \& Subrahmanyan, V. (1958). Ann. Biochem. 18, 5 r.

McCance, R. A. \& Walsham, C. M. (1948-9). Brit. F. Nutr. 2, 26. 
McCance, R. A. \& Widdowson, E. M. (1935). Biochem. F. 29, 2694.

Murthy, H. B. N., Reddy, S. K., Swaminathan, M. \& Subrahmanyan, V. (1955). Brit. F. Nutr. 9, 203. Murthy, H. B. N., Swaminathan, M. \& Subrahmanyan, V. (1954). Brit. F. Nutr. 8, 1 1.

Nicholls, L. \& Nimalasuriya, A. (1939). F. Nutr. 18, 563 .

Subrahmanyan, V., Kuppuswamy, S., Ramarao, G., Swaminathan, M. \& Bhatia, D. S. (1954). Bull. cent. Fd. technol. Res. Inst. 3, I87.

Sur, G., Swaminathan, M. \& Subrahmanyan, V. (1955). Bull. cent. technol. Res. Inst. 4, r33.

Widdowson, E. M. \& McCance, R. A. (1954). Spec. Rep. Ser. med. Res. Coun., Lond., no. 287.

Widdowson, E. M. \& Thrussell, L. A. (195I). In Spec. Rep. Ser. med. Res. Coun., Lond., no. 275, p. 296. 